\title{
The Helix: Editorial Changes
}

\author{
Neurol Genet December 2020 vol. 6 no. 6 e518. doi:10.1212/NXG.0000000000000518
}

There are many ways to judge a journal. Among the myriad of ways to choose a journal for reading manuscript submission is the impact factor (IF), which has played an outsized role in determining the presumed importance of a given journal. More about this below, but first to the news: Neurology ${ }^{\oplus}$ Genetics has received its first IF. It took 5 years after founding of the journal and publication of the first issue in June 2015. ${ }^{1}$

Much has been written about IFs, and there is no need to revisit past discourse. Most of us, however, will know little about the history of the factor. A great read is, "The agony and ecstasy: the history and meaning of the journal impact factor," by Eugene Garfield, ${ }^{2}$ who is considered the father of the IF. Garfield retraces his own steps that led to publishing the idea of an IF in Science in 1955 and the "primordial reference for the concept of the Science Citation Index," which had its first publication in $1961 .^{3}$ Students doing their theses in the 60s, 70s, and 80s will certainly remember the large printed volumes in the university library, where one could look up citations to a particular article. Often this strategy was more informative than searching other existing catalogs for a combination of key words.

As Garfield mused, "In 1955, it did not occur to me that 'impact' would one day become so controversial. Like nuclear energy, the impact factor is a mixed blessing. I expected it to be used constructively while recognizing that in the wrong hands it might be abused."

So how was the IF for Neurology: Genetics actually computed? The 2020 IF for Neurology: Genetics looks at citations in 2019 to citable articles published in Neurology: Genetics in 2017 and 2018. We published a total of 85 articles in 2017 and 75 in 2018. These numbers include full-length articles, reviews, and clinical scientific notes. Of these, 49 articles and reviews were counted as citable items in 2017 and 67 in 2018.

There were 230 citations of citable articles in 2017 and 177 for those published in 2018 . Thus, the IF was 407 divided by $(49+67)$ giving an IF of 3.5. The official calculation of the IF is computed by an outside organization, in past years by the Institute for Scientific Information, which was founded by Paul Garfield, and for the last 2 years by Clarivate Analytics.

As important as the IF may be, there are many other factors that determine the impact of a journal, which one might call factors of impact. More than ever, it is the individual article that has impact on the respective field. With modern search tools such as PubMed and Google Scholar, it is simple and convenient to identify articles by author, by text, or by key words in the title or abstract, and in the case of Google Scholar, by searching for articles that referenced a particular source. Open access to published articles has become more important than ever as the identified article can be downloaded in its entirety, directly and with a simple click from the search page.

The building blocks of a great journal in addition to the quality of articles themselves are the quality of editors and the expertise and timeliness of reviewers. The editor and associate editors provide the 
platform to select and evaluate impactful and excellent articles. We value diversity in our associate editors, both in terms of gender and geographic distribution as well in our reviewers with the ability to choose from an international database.

I want to end this short expose on factors of impact with a plea. The quality of a published article is dependent on the quality of the review. Editors of virtually all journals share one experience: major reasons for review delays are denial of review requests by busy experts in the field or forgetting to submit a review once accepted. Reviewing is a time-honored activity for researchers with benefits for the reviewer and the reviewee. It is also a great opportunity to mentor junior colleagues and to include individuals from diverse backgrounds by coreviewing articles and pairing junior scientists with more senior reviewers. We hope that we can count on all of you as members of the international neurogenetics community to submit high-quality articles and to participate actively in the review process.

\section{Study funding}

No targeted funding reported.

\section{Disclosure}

S.M. Pulst serves on the editorial boards of the Journal of Cerebellum, NeuroMolecular Medicine, Experimental Neurology, Neurogenetics, and Nature Clinical Practice Neurology and as Editor-in-Chief of Current Genomics; receives research support from the NIH and the National Ataxia Foundation; has served on the speakers' bureau of Athena Diagnostics; receives publishing royalties from Churchill Livingston, AAN Press, Academic Press, and Oxford University Press; has consulted for Ataxion Therapeutics; has received license fee payments from Cedars-Sinai Medical Center; holds multiple patents; and receives an honorarium from the AAN as the Editor of $\mathrm{Neu}$ rology: Genetics. Go to Neurology.org/NG for full disclosures.

\section{References}

1. Pulst SM. Welcome to Neurology: Genetics. Neurol Genet 2015;1:e2. doi: 10.1212/01. NXG.0000464293.80983.72.

2. Garfield E. The agony and the ecstasy-the history and meaning of the journal impact factor (pdf). Chicago: International Congress on Peer Review and Biomedical Publication; 2005. Available at: http://garfield.library.upenn.edu/papers/jifchicago2005.pdf. Accessed August 14, 2020.

3. Garfield E. Citation indexes to science: a new dimension in documentation through association of ideas. Science 1955;122:108-111. 


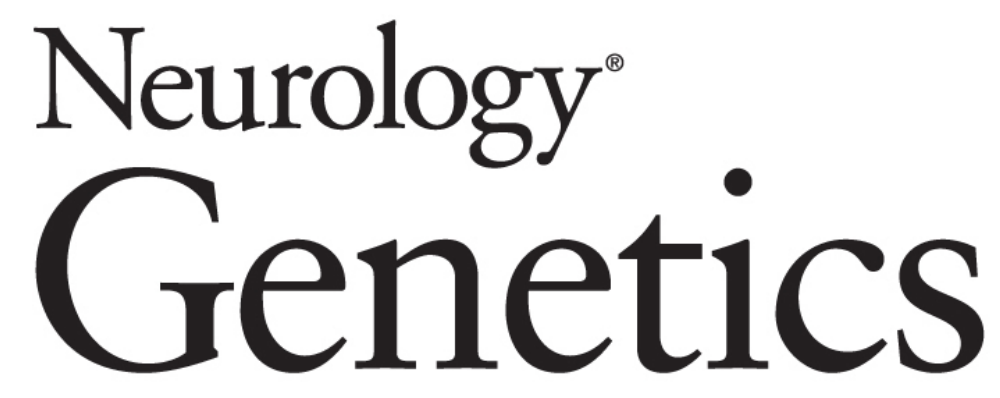

The Helix: Editorial Changes

Stefan M. Pulst

Neurol Genet 2020;6;

DOI 10.1212/NXG.0000000000000518

This information is current as of December 3, 2020

\section{Updated Information \&} Services

References

Permissions \& Licensing

Reprints including high resolution figures, can be found at: http://ng.neurology.org/content/6/6/e518.full.html

This article cites 2 articles, 2 of which you can access for free at: http://ng.neurology.org/content/6/6/e518.full.html\#\#ref-list-1

Information about reproducing this article in parts (figures,tables) or in its entirety can be found online at:

http://ng.neurology.org/misc/about.xhtml\#permissions

Information about ordering reprints can be found online: http://ng.neurology.org/misc/addir.xhtml\#reprintsus

Neurol Genet is an official journal of the American Academy of Neurology. Published since April 2015, it is an open-access, online-only, continuous publication journal. Copyright Copyright ( 2020 The Author(s). Published by Wolters Kluwer Health, Inc. on behalf of the American Academy of Neurology.. All rights reserved. Online ISSN: 2376-7839.

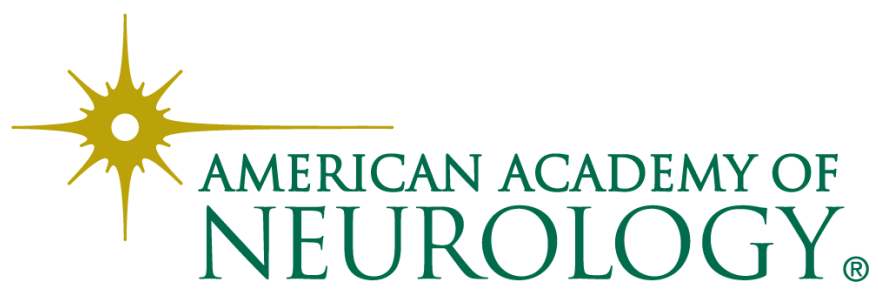

